\title{
Pengembangan Metode Identifikasi Kerusakan DNA Spermatozoa Ternak
}

\section{Development Method of Livestock Sperm DNA Damage Identification}

\author{
Teguh Ari Prabowo, ${ }^{1}$ R. Iis Arifiantini, ${ }^{2}$ Dondin Sajuthi, ${ }^{3}$ Uus Saefullah ${ }^{4}$ \\ ${ }^{1}$ Program Studi Biologi Reproduksi, Sekolah Pascasarjana, Institut Pertanian Bogor \\ ${ }^{2}$ Divisi Reproduksi, Departemen Klinik Reproduksi dan Patologi, \\ Fakultas Kedokteran Hewan, Institut Pertanian Bogor \\ ${ }^{3}$ Divisi Penyakit Dalam, Departemen Klinik Reproduksi dan Patologi, \\ Fakultas Kedokteran Hewan, Institut Pertanian Bogor \\ ${ }^{4}$ Pusat Studi Satwa Primata, Institut Pertanian Bogor \\ E-mail: teguhariprabowo@yahoo.com
}

\begin{abstract}
The success of artificial insemination is very much determined by the quality of spermatozoa. The detection or identification of damaged chromatin of spermatozoa DNA is very important to forsee the adverse clinical outcome. However, the method of identification is still depended on expensive imported kits. Therefore, the objective of this research was to developed an identification kit to determine the quality of livestock spermatozoa DNA chromatin. This study consist of three step. Step 1) Determination of low melting point agarose (LMP-agarose) concentration which is $0,6 \%, 0,7 \%$ and $0,8 \%$. 2) Comparison of three lysis solution (LS) which is LS I (0.4M Tris, $0.8 \mathrm{M}$ DTT, $1 \%$ SDS, pH 7.5), LS II (0.4M Tris, $2 \mathrm{M} \mathrm{NaCl}, 1 \%$ SDS , pH 7.5), and LS III (0.4M Tris-HCl, $2 \mathrm{M} \mathrm{NaCl}, 1 \%$ SDS 0,05 M EDTA, pH 7.5). 3) Comparison different staining which is Eosin yellow and Methylene blue. The results showed that $0.6 \%$ LMP-agarose demonstrated the best concentration to "trapped the spermatozoa" compared for sheep and goats. whereas the three concentration of spermatozoa cows can not be used to trap spermatozoa cow. The best formulation to lysis the membrane was LS III ( $0.4 \mathrm{M}$ Tris $-\mathrm{HCl}, 2 \mathrm{M} \mathrm{NaCl}, 1 \% \mathrm{SDS} 0,05 \mathrm{M}$ EDTA). The best staining was eosin yellow and methylene blue with 2:1 ratio.
\end{abstract}

Keywords: Chromatin, spermatozoa, LMP-agarose, lysis solution, staining

\begin{abstract}
Abstrak
Keberhasilan program Inseminasi Buatan (IB) ditentukan oleh kualitas spermatozoa, salah satunya adalah identifikasi kerusakan kromatin DNA. Identifikasi kerusakan kromatin DNA sangat penting dilakukan untuk mengetahui kegagalan yang dipengaruhi oleh faktor klinik reproduksi. Penelitian ini bertujuan untuk mengembangkan kit identifikasi kerusakan kromatin DNA spermatozoa ternak yang saat ini masih impor dengan harga yang mahal. Penelitian terdiri dari tiga tahap, tahap I penentuan konsentrasi Low Melting Point-agarose (LMPagarose), tahap II penentuan lysis solution (LS), dan tahap III pengujian pewarnaan kromatin DNA spermatozoa. Konsentrasi LMP-agarose yang digunakan adalah $0,6 \%, 0,7 \%$ dan $0,8 \%$. Konsentrasi terbaik selanjutnya dilisiskan menggunakan tiga jenis LS, diantaranya jenis LS, ke satu $(0,4 \mathrm{M}$ Tris, $0,8 \mathrm{M}$ DTT, $1 \%$ SDS), jenis LS ke dua $(0,4 \mathrm{M}$ Tris, $2 \mathrm{M} \mathrm{NaCl}, 1 \% \mathrm{SDS})$, dan jenis LS ke tiga (0,4M Tris-HCl, $2 \mathrm{MNaCl}, 1 \%$ SDS 0,05M EDTA) sedangkan untuk pengujian pewarnaan kromatin DNA menggunakan pewarnaan Eosin yellow (Eosin Y), Eosin dan Methylene blue. Hasil penelitian menunjukkan bahwa konsentrasi 0,6\% LMP-agarose merupakan konsentrasi agarose terbaik yang dapat digunakan untuk menjebak spermatozoa domba dan kambing, sedangkan pada spermatozoa sapi ketiga konsentrasi tersebut tidak dapat digunakan untuk menjebak spermatozoa. Lysis solution (LS) terbaik adalah LS formulasi ke tiga $(0,4 \mathrm{M}$ Tris- $\mathrm{HCl}, 2 \mathrm{M} \mathrm{NaCl}, 1 \% \mathrm{SDS} 0,05 \mathrm{M}$ EDTA, $\mathrm{pH} 7,5$,), sedangkan untuk pewarnaan yang terbaik menggunakan pewarnaan Eosin yellow dan Methylene blue dengan perbandingan 2:1.
\end{abstract}

Kata kunci: Kromatin, spermatozoa, LMP-agarose, lysis solution, pewarnaan. 


\section{Pendahuluan}

Keberhasilan program Inseminasi Buatan (IB) ditentukan oleh beberapa faktor di antaranya faktor sumber daya manusia (SDM) yaitu inseminator, peternak, faktor betina dan faktor pejantan, dalam hal ini adalah kualitas semen yang diinseminasikan. Semen beku berdasarkan Badan Standardisasi Nasional (BSN) dengan no SNI 4869.1:2008 mengenai semen beku sapi, post thawing harus menunjukkan spermatozoa hidup dan bergerak maju (motil spermatozoa) minimal empat puluh persen dan skor gerakan spermatozoa minimal dua. Morrell and Rodriguez-Martinez (2009) menyatakan sub populasi spermatozoa yang dapat memfertilisasi ovum adalah spermatozoa yang motil, viable dengan morfologi yang normal serta mempunyai kromatin yang intact.

Penyebab kerusakan kromatin DNA menurut Rodriguez-Martinez (2007) dapat terjadi karena perubahan polimer DNA dan secara terus menerus terpapar pada lingkungan fisik dan kimia yang bervariasi yang berpotensi mengubah struktur alamiah DNA tersebut. Perubahan ini akan memengaruhi proses replikasi (Oliva, 2006) dan transkripsi DNA yang mengarah pada kerusakan DNA (Evenson et al., 2002). Kerusakan kromatin DNA spermatozoa semakin diakui sebagai faktor penting penyebab terjadinya infertilitas. Beberapa kasus menunjukkan terdapat korelasi antara kerusakan kromatin DNA spermatozoa dengan fertilitas (Evenson and Wixon 2006), penurunan integritas membran plasma (Nishizono et al., 2004), kesalahan kondensasi kromatin, dan peningkatan fragmentasi DNA (Yildiz et al., 2007). Priyanto et al. (2015) membandingkan pengujian DNA spermatozoa menggunakan cytochemical assay dengan pewarnaan toluidine blue dan Kit halomax, hasilnya menunjukkan Kit halomax lebih sensitif untuk menguji kerusakan spermatozoa setelah pembekuan dengan melihat dispersi kromatin yang terjadi.
Kit halomax merupakan produk komersial dan harus diimpor sehingga harganya mahal dan tidak efisien karena satu jenis kit hanya digunakan untuk menguji kerusakan kromatin DNA pada satu jenis ternak saja, selain itu penggunaan Kit halomax berdasarkan prosedurnya diamati menggunakan mikroskop fluorescent yang sulit ditemui di Balai Inseminasi Buatan (BIB). Pengujian kromatin DNA spermatozoa ini bertujuan untuk mengembangkan metode pengujian dispersi kromatin DNA buatan sendiri dengan prinsip kerja yang sama dengan Kit halomax tetapi dapat digunakan pada spermatozoa ternak dengan morfometri spermatozoa yang hampir sama seperti domba, kambing dan sapi.

\section{Materi dan Metode}

\section{Menentukan konsentrasi Low Melting Point-agarose (LMP-agarose) terbaik}

\section{a. Pembuatan LMP-agarose}

Konsentrasi LMP-agarose yang digunakan pada penelitian ini ada tiga jenis yaitu $0,6 \% ; 0,7 \%$ dan $0,8 \%$. LMP-agarose yang telah dibuat disimpan dalam suhu $5^{\circ} \mathrm{C}$. Semen segar dari sapi, domba dan kambing yang digunakan untuk menguji LMPagarose ini dikoleksi kemudian dievaluasi secara makro dan mikroskopis setelah itu diencerkan dengan Phosphate Bufer Saline hingga 20 juta sel $/ \mathrm{ml}$

\section{b. Pengujian Kerapatan LMP-agarose}

Semen segar (sapi, kambing dan domba) yang sudah diencerkan diteteskan ke dalam LMP-Agarose yang sebelumnya telah dilelehkan. Sebanyak $20 \mu \mathrm{L}$ campuran LMP-agarose dengan semen diteteskan ke dalam sumuran pada object glass khusus dan ditutup dengan cover glass. Object glass diinkubasi dalam lemari es $\left(4^{\circ} \mathrm{C}\right)$. Cover glass diambil, selanjutnya object glass dievaluasi di bawah mikroskop binokuler (Olympus CX21). Spermatozoa pada masing-masing konsentrasi dihitung dari sepuluh lapangan pandang. 
Pengujian jenis lysis solution (LS) untuk melisis membran spermatozoa

\section{a. Persiapan lysis solution}

Jenis LS yang digunakan adalah LS I $(0,4 \mathrm{M}$ Tris, $0,8 \mathrm{M}$ DTT, $1 \%$ SDS, $\mathrm{pH} 7,5)$, LS II (0,4M Tris, $2 \mathrm{M} \mathrm{NaCl}, 1 \%$ SDS , pH 7,5), dan LS III (0,4M Tris$\mathrm{HCl}, 2 \mathrm{M} \mathrm{NaCl}, 1 \%$ SDS 0,05M EDTA, pH 7,5). Seluruh LS yang telah dibuat disimpan pada tabung, dan disimpan pada suhu $5^{\circ} \mathrm{C}$.

\section{b. Sampel semen untuk pengujian LS.}

Struktur sel pada spermatozoa sapi, kambing dan domba sama sehingga pengujian jenis lysis solution (LS) digunakan hanya satu jenis spermatozoa ternak yaitu spermatozoa sapi. Sampel semen yang digunakan adalah semen beku sapi dari BIB Lembang. Semen beku disimpan pada kontainer $\left(-196^{\circ} \mathrm{C}\right)$. Sebelum pengujian semen beku dithawing pada suhu $37^{\circ} \mathrm{C}$ selama 30 detik. Selanjutnya semen beku sapi diencerkan menggunakan Phosphate Buffered Saline (PBS), dengan konsentrasi akhir 15-20 juta sel/mL.

\section{c. Pengujian LS pada semen beku}

Sebanyak $50 \quad \mu \mathrm{L}$ semen yang sudah diencerkan, dimasukan ke dalam tabung yang berisi LMP-agarose (pada tahap I) yang telah dilelehkan lalu dihomogenkan. Campuran tersebut selanjutnya diteteskan dalam tiga buah object glass, ditutup dan diinkubasi pada suhu $4^{\circ} \mathrm{C}$ selama 5 menit. Cover glass diangkat, setelah itu dilakuan pengamatan menggunakan mikroskop binokuler.

Setiap object glass diteteskan dengan jenis LS yang berbeda masing-masing LS I, LS II dan LS III. Seluruh object glass didiamkan selama 5 menit. Setelah itu direndam dalam aquadest 5 menit, dilanjutkan direndam dalam etanol 70\%, 90\%, 100\% (masing-masing 4 menit), kemudian dikeringkan. Setelah itu preparat direndam dalam aquadest selama 5 menit, dikeringanginkan, direndam dalam eosin yellow (Eosin Y) 1\% selama 5 menit, direndam dalam aquadest selama 5 menit, dilanjutkan dengan direndam dalam methylen blue selama 5 menit dan terakhir direndam dalam aquadest selama 5 menit. Preparat diangkat dan dikeringanginkan, selanjutnya dilakukan pengamatan di bawah mikroskop binokuler dengan pembesaran 400X.

\section{Pengujian jenis pewarnaan}

\section{a. Persiapan pewarna.}

Jenis pewarnaan yang digunakan pada penelitian ini adalah; a) Pewarnaan bertahap Eosin Y dengan Methylene blue 1:1, b) Pewarnaan campuran Eosin Y dengan Methylene blue 1:1, c) Pewarnaan bertahap Eosin Y dengan Methylene blue 2:1.

\section{b. Sampel semen}

Semen yang digunakan adalah semen beku sapi, domba dan kambing dari BIB Lembang. Prosedur thawing dan pengenceran semen sama dengan yang digunakan pada tahap II, kemudian dimasukkan dalam LMP-agarose terbaik tahap I, dan dimasukkan pada LS terbaik tahap II.

\section{c. Pengujian pewarna}

Semen diwarnai dengan tiga macam pewarnaan berbeda sesuai metode tahap II. Preparat diamati di bawah mikroskop binokuler dengan perbesaran 400X menggunakan green filter.

\section{Hasil dan Pembahasan}

\section{Konsentrasi LMP-agarose terbaik untuk menjebak spermatozoa ternak}

LMP-agarose merupakan polisakarida turunan yang digunakan untuk memisahkan DNA berukuran lebih dari 100 bp, sedangkan untuk memisahkan DNA dengan ukuran lebih pendek dapat digunakan gel poliakrilamid (Surzycky 2000). Bartlett and Stirling (2003) menyatakan semakin tinggi konsentrasi agarose, semakin kaku gel yang dibuat dan pori-pori yang terbentuk semakin rapat sehingga sukar untuk 
dilewati molekul-molekul DNA. Pada penelitian ini terbukti semakin tinggi konsentrasi spermatozoa maka semakin banyak spermatozoa yang terjebak.

Pada spermatozoa sapi diketahui konsentrasi 0,8\% LMP-agarose merupakan konsentrasi terbanyak untuk menjebak spermatozoa dengan jumlah 30,69 $\pm 1,28$ sel, pada kambing dan domba konsentrasi LMP-agarose yang sama spermatozoa terjebak juga paling banyak yaitu $28,29 \pm 0,81$ dan $26,58 \pm 1,47$ sel (Tabel 1).

Tabel 1 Jumlah spermatozoa yang terjebak di dalam LMP-agarose (rata-rata $\pm \mathrm{SD}$ )

\begin{tabular}{lcc}
\hline Jenis Ternak & Konsentrasi & Spermatozoa \\
\hline \multirow{2}{*}{ Sapi } & $0,6 \%$ & $20,100 \pm 0,562$ \\
& $0,7 \%$ & $24,310 \pm 1,272$ \\
& $0,8 \%$ & $30,690 \pm 1,278$ \\
\hline \multirow{3}{*}{ Kambing } & $0,6 \%$ & $14,950 \pm 0,712$ \\
& $0,7 \%$ & $21,770 \pm 1,479$ \\
& $0,8 \%$ & $28,290 \pm 0,810$ \\
\multirow{2}{*}{ Domba } & $0,6 \%$ & $15,795 \pm 1,148$ \\
& $0,7 \%$ & $20,545 \pm 1,179$ \\
& $0,8 \%$ & $26,585 \pm 1,468$ \\
\hline
\end{tabular}

Merujuk kepada Cerolini et al. (2001) jumlah spermatozoa dalam satu lapang pandang agar mudah diamati adalah 10-15 sel spermatozoa. Berdasarkan hal tersebut pada penelitian ini konsentrasi LMP- agaroseyang paling baik untukmenjebak spermatozoa adalah $0,6 \%$ pada spermatozoa kambing dan domba. Pada spermatozoa sapi, jumlah spermatozoa yang terjebak pada LMP-agarose konsentrasi 0,6\% masih melebihi batas lapang pandang terbaik, sehingga disarankan konsentrasi agarose dapat diturunkan untuk memudahkan pengamatan.

Morfometri spermatozoa sapi lebih besar dibandingkan dengan sapi dan domba. Panjang kepala spermatozoa sapi $0,6 \mu \mathrm{m}$ lebih panjang dan sekitar 0,20 $\mu \mathrm{m}$ lebih lebar dari spermatozoa kambing dan domba. Oleh karena itu, pada konsentrasi LMPagarose $0,6 \%$ jumlah spermatozoa sapi akan lebih banyak terjebak dibandingkan kedua ternak lainnya.

\section{Lysis Solution (LS) terbaik untuk melisiskan membran spermatozoa ternak}

Menurut Holme and Hazel (1998) tahap pertama dalam isolasi DNA adalah proses perusakan atau penghancuran membran dan dinding sel yang bertujuan untuk mengeluarkan isi sel. Metode yang dapat digunakan untuk isolasi plasmid antara lain yaitu boiling lysis, lysis with detergent, mechanical lysis, alkaline lysis, dan enzimatic digestion. Hasil penelitian pada tahap kedua dapat dilihat pada Gambar 1 .
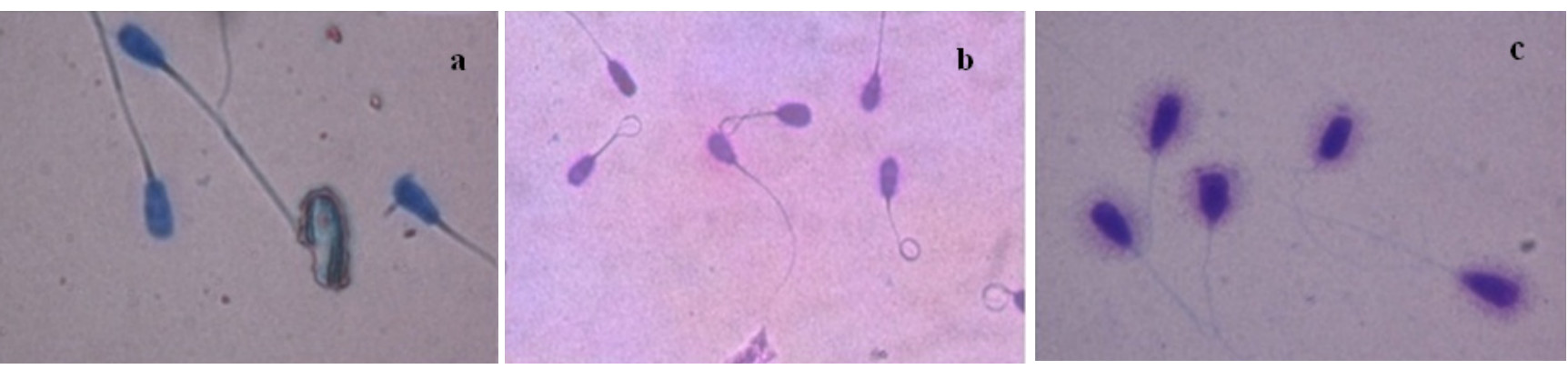

Gambar 1(a) Spermatozoa dengan LS I; (b) Spermatozoa dengan LS II; (c) Spermatozoa dengan LS III

Hasil penelitian ini menunjukan bahwa LS III dapat digunakan pada ketiga ternak tersebut (Gambar 1). Hal ini karena ketiga komposisi membran sel dari ketiga spermatozoa ternak tersebut hampir sama, yaitu terdiri dari $43 \%$ lipid, $48 \%$ protein, $9 \%$ karbohidrat dan zat-zat lain yang bergabung bersama secara non kovalen.
Formulasi LS III yaitu 0,4M Tris-HCl, 2M $\mathrm{NaCl}, 1 \%$ SDS 0,05M EDTA merupakan LS terbaik, hal tersebut dapat dilihat dari Gambar 1.c kromatin DNA spermatozoa pada LS III terlihat lebih jelas bila dibandingkan dengan kedua LS I dan LS II. 

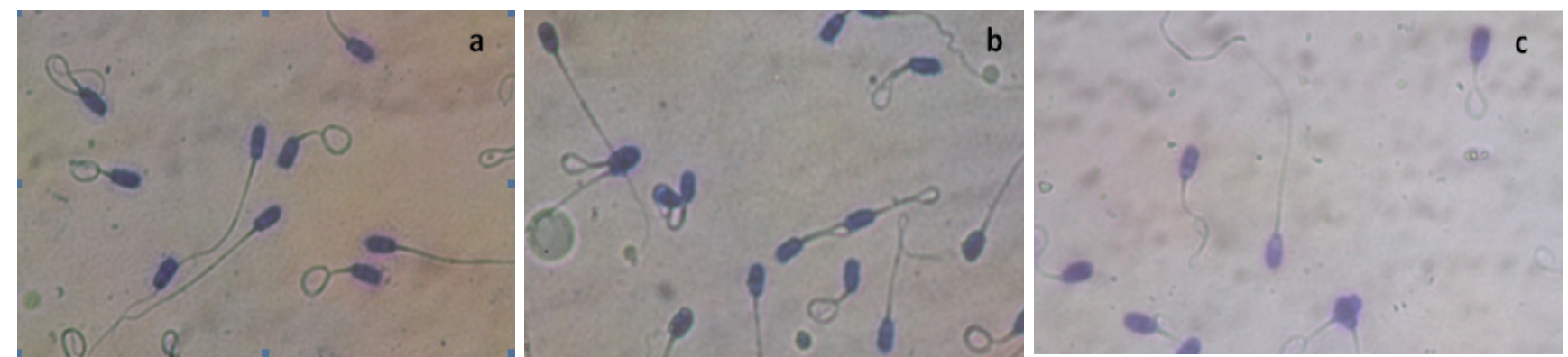

Gambar 2. a) Perbandingan konsentrasi methylene blue dan eosin Y 1:1; b) Perbandingan konsentrasi methylene blue dan eosin Y 1:1(dicampur); c) Perbandingan konsentrasi methylene blue dan eosin Y 1:2

Chelating agent pada ethylenediamine tetraacetic acid (EDTA) diduga menyebabkan kromatin DNA yang keluar dapat terlihat dengan baik. Menurut Muladno (2002), dalam proses isolasi DNA menggunakan LS yang mengandung EDTA berfungsi merusak membran sel secara kimiawi dengan cara mengikat ion magnesium selain itu berfungsi mempertahankan integritas sel maupun aktifitas enzim nuclease yang merusak asam nukleat. Lebih lanjut Corkill and Rapley (2008) menyatakan EDTA berperan untuk menginaktivasi enzim DNase yang dapat mendenaturasi DNA yang diisolasi, EDTA juga dapat menginaktivasi enzim nuklease dengan cara mengikat ion magnesium dan kalsium yang dibutuhkan sebagai kofaktor enzim DNAse sehingga membran plasma menjadi tidak stabil.

\section{Jenis pewarnaan terbaik untuk mewarnai kromatin DNA}

Hasil penelitian menunjukkan bahwa pewarnaan eosin Y methylene blue 1:2 memberi hasil yang lebih baik (kromatin DNA mudah diamati) bila dibandingkan dengan kedua konsentrasi. Hal tersebut terlihat jelas pada Gambar 2.c bahwa kromatin dan membran sel spermatozoa dapat lebih terlihat bila dibandingkan dengan ke dua pewarna lainnya. Menurut Benson and Brown (2004), untuk mewarnai, eosin yellow (Eosin Y) secara khas digunakan dalam konsentrasi 1 sampai $5 \%$ berat berdasarkan volume, yang dilarutkan dalam air atau etanol sedangkan untuk methylene blue konsentrasi yang digunakan ialah $0,5 \%$ sampai $1 \%$.
Menurut Harley and Prescott (2002) methylene blue (MB) dan Eosin merupakan zat warna yang sering digunakan dalam pewarnaan sederhana, dimana MB dapat bekerja dengan baik pada membran sel karena bersifat basa alkalin (komponen kromofiknya bermuatan positif), sedangkan sitoplasma sel spermatozoa bersifat basofilik (suka terhadap basa) sehingga terjadilah gaya tarik antara komponen kromofor pada pewarna dengan sel spermatozoa. Hal tersebut menyebabkan sel spermatozoa dapat menyerap pewarna dengan sel spermatozoa. Eosin digunakan pada pewarnaan negatif yang merupakan pewarna asam dan memiliki komponen kromofik yang bermuatan negatif, yang juga dimiliki oleh sitoplasma spermatozoa. Pewarna tidak dapat menembus atau terpenetrasi ke dalam sel spermatozoa karena negative charge pada permukaan sel spermatozoa.

Pada penelitian ini diperoleh hasil untuk identifikasi kerusakan kromatin DNA pada domba dan kambing dapat menggunakan konsentrasi LMPagarose $0.6 \%$, menggunakan LS III dan pewarna Eosin Y Methylene blue 2:1. Pada ternak sapi disarankan agar dilakuan penelitian lebih lanjut untuk mendapatkan konsentrasi LMP-agarose yang lebih tepat.

\section{Kesimpulan}

Pengembangan metode identifikasi kerusakan DNA spermatozoa ternak domba dan kambing dapat dibuat menggunakan konsentrasi LMP-agarose 
$0,6 \%$, sedangkan pada spermatozoa sapi ketiga konsentrasi tersebut tidak dapat digunakan untuk menjebak spermatozoa sapi. Lysis solution (LS) III (0,4M Tris- $\mathrm{HCl}, 2 \mathrm{M} \mathrm{NaCl}, 1 \%$ SDS 0,05M EDTA, $\mathrm{pH} 7,5)$ merupakan LS terbaik bila dibandingkan kedua LS yang lainnya dan jenis pewarnaan terbaik menggunakan perbandingan pewarnaan Eosin Yellow Methylene blue 2:1.

\section{Daftar Pustaka}

Bartlett, J., Stirling, D. 2003. PCR Protocols Second Edition. New Jersey: Humana Press.

Benson, H. J., Brown, A.E. 2004. Benson's Microbiological Applications Laboratory Manual in General Microbiology: Complete Version. nineth Edition. The McGraw-Hill Companies, New York.

Cerolini, S., Maldjian, A., Pizzi, F., Gliozzi, T.M. 2001. Changes in sperm quality and lipid composition during cryopreservation of Boar semen. J Reprod. 121:395-401.

Corkill, G., Rapley, R. 2008. The Manipulation of Nucleic Acids: Basic Tools and Techiques in Molecular Biomethods Handbook Second Edition. Ed: Walker, J.M. Rapley, R. Humana Press. NJ.USA.

Evenson, D.P., Larson, K.L., Jost, L.K. 2002. Sperm chromatin structure assay: its clinical use for detecting sperm dna fragmentation in male infertility and comparisons with other techniques. J Androl. 23 (1): 25-43.

Evenson, D.P., Wixon, R. 2006. Clinical aspects of sperm DNA fragmentation detection and male infertiity. Theriogenology. 65:979-991.

Harley, J.P., Prescott, L.M. 2002. Laboratory Exercises in Microbiology. Fifth Edition. The McGraw-Hill Companies.

Holme, D.J., Hazel, P. 1998. Analytical Biochemistry Third Edition. London: Addision Wesley Longman.

Morrell, J.M. and H. Rodriguez-Martinez. 2009.
Biomimetic techniques for improving sperm quality in animal breeding: a review. The Open J Androl. 1 (1): 1-9.

Muladno. 2002. Seputar Teknologi Rekayasa Genetika. Pusataka Wirausaha Muda. Bogor.

Nishizono, H., Shioda, M. Takeo, T., Irie, T., Nakagata, N. 2004. Decrease of fertilizing ability of mouse spermatozoa after freezing and thawing is related to cellular injury. Bio of Reprod. 71: 973-978.

Oliva, R. 2006. Protamine and male infertility. J Hum Reprod. 12: 417-435.

Priyanto, L., Arifiantini, R.I., Yusuf, T.L. 2015. Deteksi kerusakan DNA spermatozoa semen segar dan semen beku sapi menggunakan pewarnaan toluidine blue. $J$ Vet. 16: 48-55.

Rodríguez-Martinez, H. 2007. State of the art in farm animal sperm evaluation. Reprod Fertil Dev. 19 (1):91-101.

Surzycky, R. 2000. Molecular and Cellular Biology. Wadsworth Inc., Belmont.

Yildiz, C., Ottaviani, P., Law, N., Ayearst, R. Liu, L., McKerlie, C. 2007. Effects of cryopreservation on sperm quality, nuclear DNA integrity, in vitro fertilization, and in vitro embryo development in the mouse. Bio of Reprod. 133: 585-595. 